\title{
Detection of genital human papillomavirus (HPV) DNA by PCR and other conventional hybridisation techniques in male partners of women with abnormal Papanicolaou smears
}

\author{
S N Tabrizi, J Tan, M Quinn, A J Borg, S M Garland
}

\begin{abstract}
Objective-To study the prevalence of human papillomavirus (HPV) infection, using several different hybridisation techniques, in men whose female sexual partners had cervical HPV and/or cervical intraepithelial neoplasia (CIN).

Methods-The male genital area was examined colposcopically and areas suspicious of HPV changes were biopsied. Each biopsy was subjected to histological examination and HPV DNA analysis by conventional DNA analysis such as Southern, reverse and dot blot as well as with polymerase chain reaction (PCR).

Results-Colposcopic examination of men showed 133 to be normal whilst 82 $(38 \%)$ had clinical or subclinical lesions. Of 55 colposcopically directed biopsies from the male lesions taken, detection of HPV DNA by hybridisation with conventional techniques and by PCR showed HPV DNA in $29(53 \%)$ and $47(85 \%)$ of biopsies respectively. Overall HPV types 6/11 were the predominant types. In 18 (33\%) biopsies positive by PCR, multiple types were found.

Conclusion-HPV DNA was present in the majority of biopsy specimens taken, with HPV 6/11 being the predominant type. Among methods for HPV DNA detection, PCR was the most sensitive and useful technique.
\end{abstract}

(Genitourin Med 1992;68:370-373)

Department of Microbiology

$S$ N Tabrizi

A J Borg

S M Garland

Oncology and Dysplasia Unit, The Royal Women's

Hospital, Carlton

Victoria, Australia,

3053

JTan

M Quinn

Address for correspondence Dr $S$ N Tabrizi, The Royal Women's Hospital,

Department of

Microbiology, 132 Grattan

St, Carlton, Victoria 3053, Australia.

Accepted for publication 25 June 1992

\section{Introduction}

Over 65 DNA types of human papillomavirus (HPV) have been identified to date in mucosal and dermal sites. Genital types of HPV have been strongly associated with the development of benign condylomas and anogenital carcinomas. ${ }^{1}$ In women, the risk of development of cervical cancer is strongly linked to the number of sexual partners, and age of first intercourse, and is increased for those whose partners have had previous sexual partners with cancer of the cervix. $^{23}$ In addition wives of men diagnosed with cancer of the penis have an increased rate of mortality for cancer of the cervix although not of the other types of genital cancer. ${ }^{4}$

The role of the asymptomatic male sexual partner in the infection and reinfection of his female partner has only relatively recently been addressed in the management of the women with HPV infection. In this study, male sexual partners of women being evaluated for cervical HPV, with and without cervical intraepithelial neoplasia (CIN) were studied in order to determine the prevalence of HPV infection in this population of men.

\section{Methods}

Study population

Male sexual partners of women attending the dysplasia clinic at the Royal Women's Hospital or private gynaecologists for evaluation of cervical HPV and or cervical intraepithelial neoplasia (CIN) as diagnosed by cytology (Papanicolaou smear) and histology of colposcopically directed cervical biopsies were invited to attend the hospital for evaluation of HPV infection. All were evaluated by one of us (J T).

\section{Specimen collection}

The male genital area was examined for evidence of clinical HPV lesions and after application of $5 \%$ acetic acid for subclinical lesions using a colposcope. Areas suspicious of HPV changes (aceto white, macular, microcondylomatous areas) were biopsied $\left(2-3 \times 1.5 \mathrm{~mm}^{2}\right)$, and the specimens then divided into two. One portion was placed in HPV-transport media (10 mM Tris- $\mathrm{HCl}$, $50 \mathrm{mM}$ EDTA, $150 \mathrm{mM} \mathrm{NaCl}$ and $0.1 \%$ Sodium azide, $\mathrm{pH} 7 \cdot 5$ ), and snap frozen in liquid nitrogen for HPV DNA analysis, whilst the other was placed in formalin for histology.

Eight specimens of foreskin of circumcised newborn infants were used as negative controls for HPV DNA analysis.

\section{Extraction of DNA from biopsy material}

Tissue specimens were weighed and cut into small fragments with a sterile scalpel and DNA was extracted with phenol:chloroform after initial proteinase $\mathrm{K}$ digestion by standard procedures. $^{5}$

\section{Dot blot}

Five hundred nanograms of DNA extracted from clinical biopsies were dotted, in presence of $0.4 \mathrm{~N} \mathrm{NaOH}$, onto positively charged nylon membrane Hybond $\mathrm{N}^{+}$(Amersham, Amersham, UK) using a 96 well vacuum manifold. Membranes were stored at room temperature until probed. 
Gel electrophoresis and Southern blot

Ten $\mu$ g genomic DNA from biopsies were cleaved enzymatically with restriction endonuclease $B a m \mathrm{HI}$, and restriction fragments were separated on $0.7 \%$ agarose gel electrophoresis. The electrophoretically separated DNA fragments were denatured in the gel and transferred to reinforced nitrocellulose (Schleicher \& Schuell, Keene, NH, USA) as described by Southern. ${ }^{6}$ After blotting, the nitrocellulose membranes were baked for $2 \mathrm{~h}$ at $80^{\circ} \mathrm{C}$ and prepared for hybridisation.

\section{Reverse blots}

Biopsy cellular DNA (500 $\eta \mathrm{g}$ ) was labelled with ${ }^{32} \mathrm{P}$ as described below and hybridised to Southern blot membranes containing $200 \eta \mathrm{g}$ of cloned DNA of HPV 6, 11, 16, 31, 33 cleaved with PstI and HPV 18 cleaved with EcoRI.

\section{Full-genomic HPV probes}

Recombinant pBR322 plasmid containing HPV types 6, 11, 16 and 18 were gifts from Professor Harold zur Hausen (University of Heidelberg, F R Germany). HPV 31 cloned in pBR322 and HPV 33 cloned in plink322, were gifts from A Lorincz (Bethesda Research Laboratories, Maryland, USA) and G Orth (Pasteur Institute, Paris, France) respectively. Each clone was transformed in $E$ coli $\mathrm{HB} 101$ and plasmid DNA was isolated by a cleared lysate technique followed by isopycnic banding of plasmic DNA in a caesium chloride-ethidium bromide gradient. ${ }^{7}$ Full-genomic HPV DNA types were isolated by cleaving the cloned DNA with the appropriate restriction endonuclease enzyme for release of insert from vector (Boehringer Mannheim, F R Germany), electrophoresed at $4^{\circ} \mathrm{C}$ on a $0.6 \%(w / v)$ low-gelling agarose (FMC BioProducts, Rockland, ME, USA) and extracted as described by Maniatis et al. ${ }^{5}$

Hybridisation conditions with full-genomic probes All hybridisation assays were performed by one author (SNT), and each different hybridisation procedure carried out for each specimen was done blinded to the results of previous assays.

All membranes were prehybridised overnight at $68^{\circ} \mathrm{C}\left(\mathrm{Tm}-25^{\circ} \mathrm{C}\right)$ in $6 \times \mathrm{SSC}$ $(1 \times$ SSC is $0.15 \mathrm{M} \mathrm{NaCl}, 0.015 \mathrm{M}$ sodium citrate), $0 \cdot 1 \%(\mathrm{w} / \mathrm{v})$ polyvinylpyrollidon, $0 \cdot 1 \%$ $(\mathrm{w} / \mathrm{v})$ bovine serum albumin, $0 \cdot 1 \%(\mathrm{w} / \mathrm{v})$ Ficoll, $0.5 \%(\mathrm{w} / \mathrm{v})$ sodium dodecyl sulphate (SDS) and $50 \mu \mathrm{g} / \mathrm{ml}$ of denatured salmon sperm DNA. Cold pBR322 DNA (digested with HpaII endonuclease) was added to the prehybridisation solution of the dot blots as described previously. ${ }^{8}$

Purified inserts or biopsy DNA were labelled with $a-{ }^{32} \mathrm{P}$-dATP and $a-{ }^{32} \mathrm{P}$-dCTP using a commercial nick translation kit (Bresatec Ltd, Adelaide, Australia) to a specific activity of $1 \times 10^{8} \mathrm{cpm} / \mu \mathrm{g}$. Labelled inserts were denatured by heating at $100^{\circ} \mathrm{C}$ for 5 minutes, chilled on ice and added to the duplicate membranes. To the membranes which received pBR322 blocking in the prehybridisation solu- tion, $5 \mu \mathrm{g}$ of pBR322 (digested with HpaII and denatured as described above) was also added with the probes. Denatured salmon sperm DNA $(50 \mu \mathrm{g} / \mathrm{ml})$ was added to all membranes and hybridisation was carried out for 18 hours at $68^{\circ} \mathrm{C}$.

Membranes were washed at $68^{\circ} \mathrm{C}$ in $2 \times$ SSC twice for 15 minutes each, in $2 \times \mathrm{SSC}, 0.1 \%$ (w/v) SDS for 30 minutes, and in $0.1 \times$ SSC for 10 minutes. Membranes were then air dried and subjected to autoradiography with use of amplifying screens (Dupont, Wilmington, DE USA) on Hyperfilm (Amersham) for 24 hours.

Specimens screened by conventional hybridisation techniques were classified as positive, if any of the three tests ie dot blot, reverse blot, or Southern blot was positive.

\section{Polymerase chain reaction}

DNA from biopsy specimens were amplified using the heat-stable Thermus aquaticus (Taq) polymerase.' Reactions contained $0.5 \mu \mathrm{g}$ of DNA extracted from biopsies or of control DNA; $0.2 \mu \mathrm{g}$ of $\mathrm{Ll}$ consensus primers, $0.1 \mu \mathrm{g}$ of each of the $\beta$-globin primers GH20-PC04; $200 \mu \mathrm{M}$ of each of dATP, dGTP, dCTP and dTTP; $2 \cdot 5$ units Taq polymerase (Perkin-Elmer Cetus, Norwalk, Conn, USA) $1 \times$ reaction buffer $\left(50 \mathrm{mM} \mathrm{KCl}, 2 \mathrm{mM} \mathrm{MgCl}_{2} 10 \mathrm{mM}\right.$ Tris pH 8.3) in $100 \mu \mathrm{l}$. Ll consensus primers pairs MY09-MY11, described by Manos et $a l^{10}$ was used to amplify an approximately $450 \mathrm{bp}$ fragment of HPV DNA, and $\beta$-globin primers were included as a positive internal control which simultaneously amplified a human $\beta$-globin product of $260 \mathrm{bp}$. DNA from cloned HPV 6, 11, 16, 18, 31 and 33 was used as positive controls and DNA extracted from foreskin of circumcised infants as negative controls.

Each reaction was amplified 30 cycles in a multi-water bath system (Bartelt Instruments, Heidelberg, Victoria) using parameters of $94^{\circ} \mathrm{C}$ for 1 minute, $55^{\circ} \mathrm{C}$ for 1 minute and $72^{\circ} \mathrm{C}$ for 1 minute. Prior to the first cycle, reactions were heated for 5 minutes at $94^{\circ} \mathrm{C}$ and an additional 10 minutes was included at the final $72^{\circ} \mathrm{C}$ elongation cycle.

Aliquots of $10 \mu \mathrm{l}$ of the amplification products were separated by electrophoresis on $2 \%$ agarose gels, visualised by UV illumination following ethidium bromide staining, transfered to nylon membranes and probed with $\mathrm{Ll}$ general probes as described by Resnick et al. ${ }^{11}$

Specimen contamination and carryover was prevented by using positive displacement pipettes, prior aliquoting of all reagents and performing pre- and post-PCR steps in different rooms specifically allocated for PCR.

\section{Results}

Of the 215 men examined, 133 (62\%) were normal on colposcopic examination whist 68 (32\%) had clinically evident lesions, 14 of whom also had changes on colposcopy consistent with sub-clinical HPV infection and 14 (6\%) had lesions consistent with sub-clinical 
Table 1 Prevalence of HPV DNA in biopsy samples of male patients using conventional hybridisation techniques (dot blot, reverse blot, Southern blot) and PCR

\begin{tabular}{|c|c|c|c|c|c|c|c|}
\hline \multirow[b]{2}{*}{ Detection method } & \multicolumn{5}{|c|}{ Postive } & \multirow[b]{2}{*}{ Negative } & \multirow[b]{2}{*}{$\mathrm{ND}^{\star}$} \\
\hline & $6 / 11$ & $16 / 18$ & Mixedt & Other $¥$ & Total & & \\
\hline \multicolumn{8}{|l|}{ Conventional } \\
\hline$\underset{(\%)}{\text { Biopsies }(n=55)}$ & $\begin{array}{l}24 \\
44\end{array}$ & $\begin{array}{l}2 \\
4\end{array}$ & $\begin{array}{l}3 \\
5\end{array}$ & & $\begin{array}{l}29 \\
53\end{array}$ & $\begin{array}{l}26 \\
47\end{array}$ & \\
\hline Controls $(n=8)$ & 0 & 0 & 0 & & 0 & 8 & \\
\hline$(\%)$ & 0 & 0 & 0 & & 0 & 100 & \\
\hline \multicolumn{8}{|l|}{$P C R$} \\
\hline Biopsies $(n=55)$ & 21 & 6 & 18 & 3 & 47 & 4 & 4 \\
\hline (\%) & 38 & 11 & 33 & 3 & 85 & $7 \cdot 5$ & $7 \cdot 5$ \\
\hline Controls $(n=8)$ & 0 & 0 & 0 & 0 & 0 & 8 & 0 \\
\hline$(\%)$ & 0 & 0 & 0 & 0 & 0 & 100 & 0 \\
\hline
\end{tabular}

${ }^{*}$ Refers to $P C R$ reactions in which $\beta$-globin band was not detected.

Indicates any of the mixed types such as $6 / 11 / 16 / 18,16 / 18 / 31 / 33$ or $6 / 11 / 16 / 18 / 31 / 33$.

$\ddagger$ Refers to PCR reaction only where the 450 bp was detected but did not hybridise to the probe types used.

infection alone. Fifty five colposcopically directed biopsies were performed. Excised biopsy specimens were $3-5 \mathrm{~mm}^{2}$ in size and yielded an avrage of $5 \mu \mathrm{g}$ of DNA. Sufficient DNA (>10 $\mu \mathrm{g}$ ) was extracted for a Southern blot in only nine specimens. HPV DNA was detected in $53 \%$ when conventional hybridisation techniques were utilised, whereas $85 \%$ were positive when PCR was used (table 1). All but four specimens were adequate for amplification by PCR. In these four specimens, the 260 bp $\beta$-globin band was not detected.

HPV DNA types $6 / 11$ were the predominant types detected by both conventional hybridsation (44\%) and PCR techniques (38\%). Three and 18 of the samples contained multiple HPV types when assessed by standard hybridisation and PCR methods respectively. In three samples, the $450 \mathrm{bp}$ product was detected on ethidium bromide-stained agarose gels, but failed to hybridise to the HPV probe types used.

A correlation of $63 \%$ was obtained when comparing positivity in PCR and conventional hybridisation tests (table 2). Samples examined by Southern blot correlated $90 \%$ with results obtained with PCR with respect to positivity and types present. All samples negative by PCR were also negative by the conventional tests.

\section{Discussion}

This study showed that $38 \%$ of the partners of women with cervical HPV and/or CIN had detectable HPV-assoicated lesions on clinical and/or colposcopic examination. In our series only 55 samples were obtained from 82 patients with lesions consistent with HPV, as most lesions were too small to biopsy. Conven-

Table 2 Comparison of conventional hybridisation with $P C R$ in diagnosis of HPV DNA in male biopsy specimens

\begin{tabular}{lllll}
\hline \multirow{4}{*}{} & \multicolumn{3}{l}{ Conventional hybridisation } \\
\cline { 2 - 5 } & Positive & Negative & Total \\
\hline \multirow{4}{*}{ PCR } & Positive & 28 & 19 & 47 \\
Negative & 0 & 5 & 5 \\
ND & 2 & 1 & 3 \\
& Total & 30 & 25 & 55 \\
\hline
\end{tabular}

^Refers to PCR reactions in which the 450 bp HPV band did not hybridise to the probes used.

Correlation $63 \%$. tional DNA hybridisation detected HPV in 29 (53\%) biopsies whilst amplification with PCR detected HPV sequences in 47 (85\%) biopsies. The addition of primer sets for amplification of a segment of the $\beta$-globin gene, ensured the presence of adequate amplifiable DNA. Only in four specimens was the $\beta$-globin band not seen and this could be attributed to presence of inhibitors or insufficinet DNA. Disparate HPV DNA positivity between the conventional and PCR detection may relate to samples being too small for detection by the former methods, or to the presence of HPV types other than those used by the conventional methods, but which the L1 general probe of the PCR could detect. The high rate of positivity observed with PCR, however, is not unexpected, since PCR is more sensitive and in our experiments gave a sensitivity of $10 \mathrm{HPV}$ DNA copies per reaction whereas the sensitivity of Southern blot was $10^{4} \mathrm{HPV}$ DNA copies. This is further exemplified in this study where specimens from the genital area were too small to provide adequate DNA to perform a Southern blot hybridisation.

Histology showed features of benign HPV infection in $73 \%$ of biopsies (unpublished observations) with HPV DNA type 6/11 predominating as determined by HPV DNA typing. Two cases had penile intraepithelial neoplasia, in both of which HPV 16 was detected (one also contained HPV 6, 11, 31 and 33). The presence of a high number of samples containing multiple HPV types by $P C R$, again could reflect the increased sensitivity of this test. It also indicates that males could serve as a reservoir of many HPV types for transmission to their partners, though they clinically do not exhibit any archetypal clinical evidence. In three samples, the $450 \mathrm{bp}$ product did not bind to the probes used which suggests that there may be HPV types present in these specimens other than those used.

PCR as a technique has been applied to the diagnosis of many other microorganisms and has been especially useful for agents which cannot be cultivated or are slow to grow, such as human immunodeficiency virus, ${ }^{12}$ herpes simplex virus related encephalitis, ${ }^{13}$ cytomegalovirus, ${ }^{14}$ and hepatitis $C$ virus. ${ }^{15}$ This technique also has the advantage that viral DNA or RNA can be detected well before traditional assays show positivity. HPV is non-cultivatable 
and diagnosis by DNA typing is restricted to recombinant DNA technology. In the understanding of the role of HPV in genital dysplasia and neoplasia, PCR can be applied especially when a limited sample is available. In circumstances similar to this study, where the quantity of biopsied tissue is very small, PCR is often the only alternative for detection of HPV DNA. However, one must be wary in interpreting PCR results in the clinical context, as PCR techniques can detect latent infection. Therefore, PCR positivity without evidence of active viral transcription may not equate with active infectivity. ${ }^{16}$ Whilst PCR has the advantage of high sensitivity, a pitfall of this new test is contamination ${ }^{17}$ which can result in false positives. To prevent this, it is recommended that PCR be performed with observance of strict sterile technique, the presence of number of external and internal controls, the presence of several negative reagent and specimen controls, the use of dedicated positive displacement pipets, frequent glove changing, and aliquoting of reagents, and the separation of areas where pre and post PCR is performed.

It is also preferable to validate the results of PCR with another sensitive established method, that is, Southern blot. However, in order to detect a single copy number gene by Southern blot, $10 \mu \mathrm{g}$ of DNA is required. In this study only nine samples yielded sufficient DNA for a Southern blot, eight correlated with respect to HPV DNA positivity and types present with the PCR results (data not shown). Therefore, interpretation of a patient's potential infectivity when using these new tools of molecular biology must be made with great caution. Many such issues will only be resolved when the virus becomes readily cultured in the laboratory.

This work was supported by grants from Royal Women's Hospital Education and Research Fund. We thank Dr Christopher Fairly for his helpful comments of the manuscript and are grateful to $\mathrm{Mr}$ Robert Rome for his assistance with the male data base.

1 zur Hausen H, Schneider A. The role of papillomaviruses in human anogenital cancer. In: Salzman NP, Howley PM, eds. The Papoviridae: the Papillomaviruses, vol 2. New York: Plenum Press, 1987;245-64.

2 Buckley JD, Harris RWC, Doll R, Vessey MP, Williams PT Case control study of the husbands of women with dysplasia or carcinoma of the cervix uteri. Lance 1981;ii:1010-4.

3 Kessler II. Venereal factors in human cervical cancer. Cancer 1977;39:1912-9.

4 Graham S, Priore R, Graham M, Browne R, Burnett W, West $D$. Genital cancer in wives of penile cancer patients. Cancer 1979;44:1870-4.

5 Maniatis T, Fritsch EF, Sambrook J. Molecular Cloning: $A$ Laboratory Manual. 2nd ed. New York. Cold Spring Harbor Laboratory Press, 1989.

6 Southern EM. Detection of specific sequences among DNA fragments separated by gel electrophoresis. $\mathcal{F} \mathrm{Mol} \mathrm{Biol}$ fragments separa

7 Clewell DB, Helinski DR. Supercoiled circular DNAprotein complex in Escherichia coli purification and induced conversion to an open circular DNA form. Proc Natl Acad Sci USA 1969;62:1159-66.

8 Tabrizi SN, Borg AJ, Garland SM. Reduction of vector contamination in detection of human papillomavirus DNA using full-length genomic DNA probes. $f$ Virol Methods 1991;32:41-7.

9 Saiki RK, Gelfand DH, Stoffel S, et al. Primer-directed enzymatic amplification of DNA with a thermostable DNA polymerase. Science 1988;239:487-91.

10 Manos MM, Ting Y, Wright DK, Lewis AJ, Broker TR, Wolinsky SM. The use of polymerase chain reaction amplification for the detection of genital human papilloamplification for the detection of genital
maviruses. Cancer Cells 1989;7:209-14.

11 Resnick RM, Cornelissen MT, Wright DK, et al. Detection and typing of human papillomavirus in archival cervical cancer specimens by DNA amplification with consensus primers. I Natl Cancer Inst 1990;82:1477-84

12 Ou C-Y, Kwok S, Mitchell SW, et al. DNA amplification for direct detection of HIV-1 in DNA of peripheral blood mononuclear cells Science 1988;238:295-7.

13 Kimura $H$, Shibata M, Kuzushima $K$, Nishhkawa $K$ Nishiyama Y, Morishima T. Detection and direct typing of herpes simplex virus by polymerase chain reaction. Med Microbiol Immunol 1990;179:177-84.

14 Demmler GJ, Buffone GJ, Schimbor CM, May RA. Detection of cytomegalovirus in urine from newborns by using polymerase chain reaction DNA amplification. $f$ using polymerase chain reaction

15 Kaneko S, Unora M, Kobayashi K, Kuno K, Murakami S, Hattori N. Detection of serum hepatitis C virus RNA Lancet 1990;335:1-3.

16 Garland SM, Faulkner-Jones BE, Fortune DW, Quinn MA Cervical cancer-what role for human papillomavirus? Med F Aust 1992;156:204-12.

17 Kwok S, Higuchi R. Avoiding false positives with PCR Nature 1989;339:237-8. 